Article

\title{
An Integrated Design Strategy for the Urban Regeneration of West Bay, Business District of Doha (State of Qatar)
}

\author{
Sarah M. Al-Thani and Raffaello Furlan *(D) \\ Department of Architecture and Urban Planning, Qatar University, Doha 3263, Qatar; althanism@gmail.com \\ * Correspondence: raffur@gmail.com
}

Received: 26 September 2020; Accepted: 27 November 2020; Published: 10 December 2020

\begin{abstract}
Emergent communities have integrated land use and transportation plan based on transit-oriented developments (TODs) and light rail transit with the sole purpose to enliven and redevelop the constructed environment. Doha has undergone some major transformation in urban growth context due to surge in the economy instigated by oil and gas production. It is noticed that the rapid growth has led to negative impacts in terms of urban design, connectivity, and transportation. It is essential to understand the impact of the TOD model with regards to the challenges and approaches in terms of planning procedures and tactics. The purpose of TOD module is to facilitate access for public transportation and to enable transit commutation which is a missing aspect in the current setting. TODs support and enable sustainable urbanism by revitalizing the livability through integration of land use schemes in the city. This paper focuses on bringing together TOD livability approaches within West Bay, the business district of Doha and its adjacent surroundings. The objective of this research is to assess the livability in West Bay with the implementation of the TOD model. The research findings help to revisit the design and application of TOD models and to enhance the livable conditions for its occupants. The finding suggests a design model based on livability, compactness, public realms, walkability, and accessibility.
\end{abstract}

Keywords: sustainable urbanism; urban regeneration; livability; integrated urban development; West Bay; central business district

\section{Introduction}

Doha as an urban development is one of the fast-growing Gulf cities, it is the capital of the state of Qatar. Doha has developed as a port village based on coastal trade, pearling and fishing activities. Since the oily discovery in 1940s, the city began to expand rapidly, with its fast growth dependent on the rising cost of gas. In the 2000s decade, the city witnessed a huge urban change that continues to the present day, marked by major global events aligned with massive internal developments in visionary policies and urban practices. Among the most important change drivers in Doha is being the host of FIFA 2022 World Cup football tournament, where a massive number of projects and construction works are being undertaken and will proceed until the event's launch. Planners and designers have adopted Western trends in architecture, such as high-rise buildings and mega projects, to reflect the global development of the city without considering the local identity and livability aspects.

Growing cities are keen to protect their urban identity and traditional values during rapid growth in population and urban areas, prioritizing the goal of improving residents' wellbeing and the city's livability. Moreover, urban regeneration is a development strategy to enhance the social activities and physical qualities of the urban environment [1]. In parallel, transit-oriented development (TOD) is strategized in improving connectivity and mobility along with fostering the quality of the urban life. 
The recent Qatar Rail project and its future plans is a promising step toward enhancing the livability of several transit villages (TODs) that contribute to the successful urban regeneration and development of many districts in Qatar. [2].

Data analysts and researchers promote TODs as a platform to implement sustainable and robust environments. The goal is to incorporate people and activities around transit stations whereby pedestrian friendly surroundings are created. In this way people can start to become less dependent on their automobile which will in turn help reduce traffic crowding, pollution, and fossil fuel energy consumption. Urban greenery should be used to enhance urban living by lowering surface temperature, increasing urban stability, and reducing energy consumption in summer [3]. TOD focuses on density, diversity, and design (3DS) which aims at underpinning and strengthening the urge to enhance density, diversity, and design around transit locations.

Doha has experienced a major urban transformation resulting in urban sprawling and inefficient land use management. Recently, this has been addressed through the realization of the valuable effect of integrated urban design and development strategies on the overall urban perception, where urban sprawl and inefficient land use is addressed through TOD models and compact developments that are more sensible to the public realm. West Bay area is an active area in Doha with the possibility in becoming a livable and regenerated model district. In addition, West Bay has two important metro stations that are key to the successful urban regeneration strategy. Few studies examined the development of regenerating and enhancing the neighborhoods and districts of Qatar and its quality of life. For instance, Furlan [4] discussed livability potential in West Bay in order to promote social interaction by surveying people living in the high-rise buildings and what strategies should be implemented to enhance livability in the area. Findings revealed that in order to enhance sense of community, publics spaces, mixed-used buildings, and variant efficient modes of mobility need to be applied efficiently in the area. This demonstrates the importance of transit-oriented development (TOD) application within a space. Renne [5] discussed number of strategies to be used while measuring TOD in any area which some were adopted in this research methodology.

Therefore, the aim of this study is to evaluate the existing situation in the West Bay district and propose a regeneration master plan to revive its sense of place and enhance its livability. West Bay is selected because of its significant location, perception as a main global hub in Doha, and due to its commercial and economic importance. This paper unfolds as following: Section 2 delivers a thorough literature review of sustainable urbanism, livability, and urban regeneration. Section 3 indicates the framework of research methodology used in this study. Section 4 outlines the results of the analysis. Section 5 discusses the analysis with the provision of guidelines and strategies integrated in a Master Plan. Lastly, the study conclusion is in Section 6, it includes some suggestions by drawing in the study main findings and providing reflections for future research investigations. Thus, this study explores (i) the principles and potential of urban regeneration and development in West Bay area, in addition to (ii) highlighting constraints and challenges that affect the livability of the West Bay. The final output is a strategic scheme and a set of recommendations that contributes to enhancing the area quality of life.

\section{Literature Review}

\subsection{Sustainable Urbanism}

In general terms sustainable developments is normally referred to as an urban design which revolves around creating an environment inclusive of designing cities. The importance of urban design is symbolic in the development of infrastructure, transportation, landscape, and buildings. The art of revamping and shaping the urban environments is what urban designing is all about. Lynch [6] elaborated and defined urban design as tool to build environments and stated that questions like what forms a city should take and the characteristics that help shape the society are all ancient questions. Lynch as one of the pioneering scholars in urban design, developed a normative theory defining a good neighborhood as the substance needed to understand livability, which is important for achieving 
livable places. His theory is based on a set of performance dimensions for the physical form of cities that are based on the values of connection and openness. The process of addressing suitable performance attributes includes three selection criteria: (1) physical human needs and constraints, (2) the cultural activities and habits linked to a specific area, and (3) attributes that have the qualities of dimensions. Lynch identified the dimensions that support human values and needs and addressed five basic dimensions, which are vitality, sense and perception, fit, access, and ownership. The selected dimensions differ according to the discipline, culture, and aims of a researcher [7]. When Omuta [8] tried to measure the objectives and subjective quality of life to examine the livability of a neighborhood in Benin City, he used five main dimensions, namely housing, employment, comfort, amenities, and socioeconomic factors.

The TOD model is of special interest to sociologists as it enables multiple uses of communities defined in terms of walking distance, with average walkability of $15 \mathrm{~min}$ [9]. TOD works by combining all forms, including both commercial and residential places, to promote walkability, which makes life easier for city residents and visitors alike. However, Calthorpe [10] has voiced a different opinion, stating that clusters of villages on transit lines are capable of increasing the sense of belonging through the features available to the community with new indoor and outdoor spaces, including parks and trees, enhancing social and community services. Reformation is needed in terms of economic, financial, and physical factors that should be considered when planning the TOD strategy considering the context of the research, namely the context of Qatar. The TOD structure includes a strategy for urban design that is aligned with the development vision of Qatar, QNV2020; to promote public interaction that has diminished because of the unavailability of open spaces. As shown in Figure 1, the approach for sustainable urbanism is based on 15 core principles, which include eco-mobility, biodiversity, and landscaping. [11].

In reality, urban design is mainly concerned with the careful and ongoing stewardship of the built environment through a multitude of public and private interventions, only some of which relate to the actual construction of new buildings and spaces. In this way, the processes of urban infrastructure, traffic management, city center management, restoration, planning and conservation, and the personalization of one's own land and properties. [12] In this respect, sustainable places are those where these current cycles of transformation and transition are channeled actively in an interconnected way towards creating a better-quality urban environment at all scales of growth. This includes "taking a comprehensive and long-term view of any change's cost and benefits and recognizing what makes cities and communities sustainable" [13]. The aim should be to minimize the lifetime environmental effects of any building by reducing the energy and materials required and waste generated at each point of the development life cycle-building, occupation, and if necessary, demolition-in order to create a more efficient urban design. This can be done by reducing reliance on services from the wider population and by reducing emissions. The use of property as a productive resource by regenerating resources, development of human compactness, and geographical focus that promote urban areas to be interconnected with structured networks operating with a holistic view of the urban and regional environment. In addition to the identification of new technologies in order to improve environment, public health, and public transportation quality to encourage the creation of mixed uses development and to optimize the advantages of proximity, flexibility, stability, and adaptability of the built-in shape.

Two advancements in urban design history-the emergence of cars and global warming-have contributed to contemporary towns' growth. The population rose steadily in the 1980s and household numbers expanded as a result, whilst accommodation is essential and urban architects and builders urged strong demand for open land to counter the negative effects on urban overpopulation. Rod Burgess [14] presented a definition of the Compact city approach: "to increase built area and residential population densities; to intensify urban economic, social and cultural activities and to manipulate urban size, form and structure and settlement systems in pursuit of the environmental, social and global sustainability benefits derived from the concentration of urban 
functions". The definition of the Compact city is built on four fundamental concepts: (1) Density: local practices need to be in proximity to allow greater accessibility to the amenities by walking, cycling, and public transit, as well as effective distribution of resources and infrastructure; (2) Intensification: new development can take place in existing metropolitan centers and not in suburbs; (3) Combination of uses: multiple operations can be combined horizontally and involve multiland uses and facilities; (4) Human scale: better chance of quality of life, also taking into account that the impact of climate.

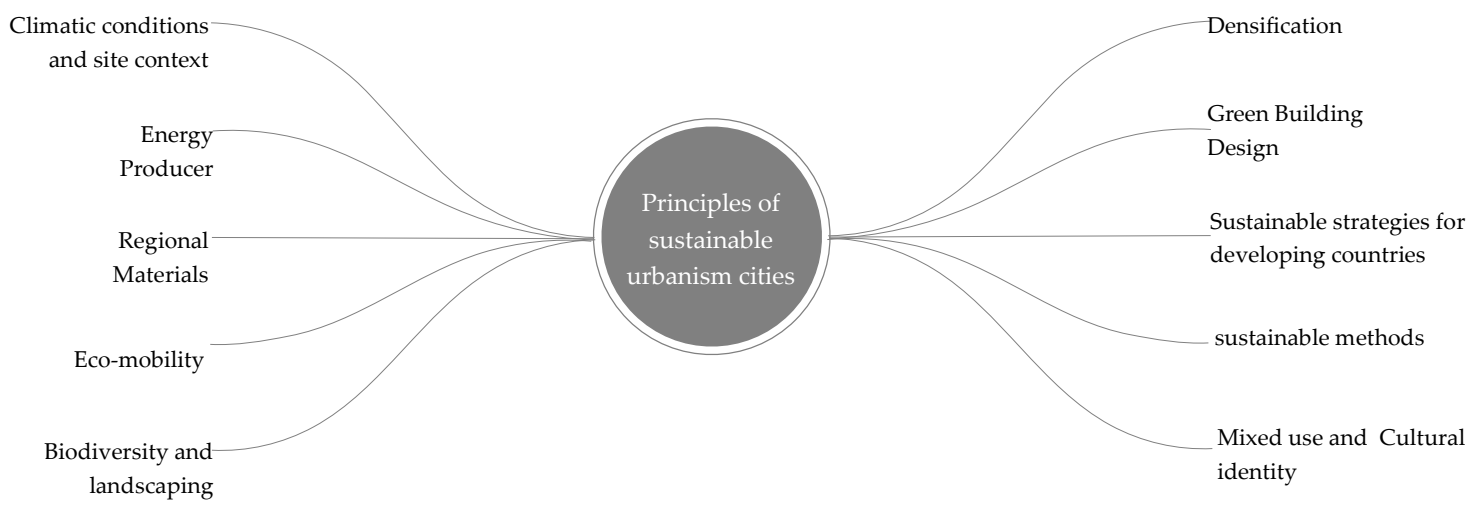

(a)

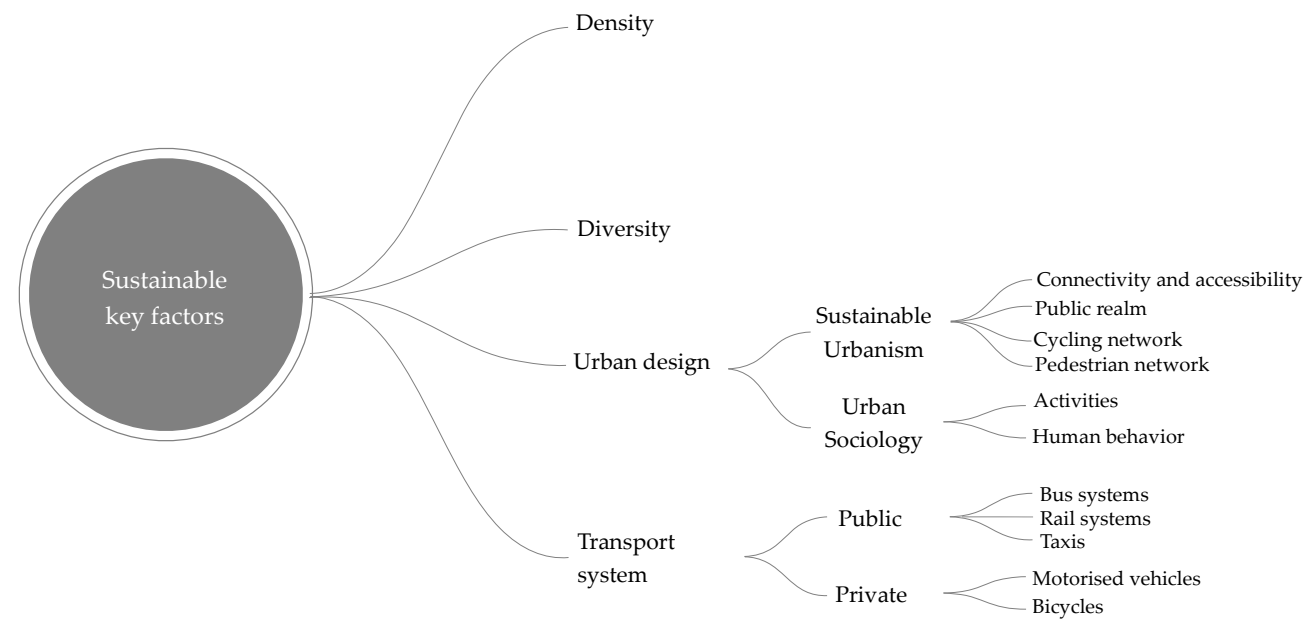

(b)

Figure 1. (a) Principles of sustainable urbanism cities; (b) sustainable key factors.

There is a requirement to restructure communities including places that are integrally important to the future generations. The planning methodology for the structure of the 15 core principles revolves around nontolerance of fossil fuels, waste, and emissions. This enables initiating the formation of a complete model that addresses the urban challenges that need to be met to curb the formation of villages and interrelated public transport systems. TOD plans to redesign communities with smart mobility and low-impact public transport systems. These plans address several points for development, which include protecting environmental areas by developing transit stations and enhancing livability of cities. Principles of sustainable urbanism are represented as the main action toward 'creating a greater sense of community'. In order to encourage interaction, involvement, and inclusion among users, the sense of community should be developed. In turn, increase opportunities to foster greater equity. The goal is to build more economically productive cities with walkable environments. In contrast, sprawls and road development have diminished the ability of cities to provide a competitive economic realm. Built environments can therefore be enhanced to make society equitable. Finally, encouraging 
sustainability. Such principles are the basis for possible solutions to the future growth of the development of urban infrastructure and fabric of cities and how this research aims to evaluate/regenerate the area chosen.

\subsection{Livability}

In the 1970s, urban theorist Donald Appleyard first used the term livability referring to neighborhood quality. Appleyard [15] specified that in order for a neighborhood to be livable, it should be comfortable with provision of protected shelter. Further, healthy neighborhoods should be free from pollution and traffic congestion and should have a sense of community and identity. With this description, Appleyard [15] determined the basic parameters for defining livable neighborhoods.

Bosselmann [16] mentioned "the original meaning of livability described conditions in neighborhoods where residents live relatively free from intrusions". Over time, the definition widens its theoretical exploration to include sustainability, safety, comfort, walkability, varied services, and transit. Lynch [6] also defined livability reference to a number of values and dimensions such as "sense, access, control, vitality, efficiency, fit and justice".

Vuchic [17] stated that "quality of life entails the general elements of home, the vicinity adjacent to the homes and the densely populated areas that impacts the safety, economic opportunities and welfare at the same time the overall health, ease of mobility and recreation". In sum, factors that contribute to quality of life are both subjective and qualitative, including a set of characteristics that affect the attractiveness of a built area for living and working. Ley and Newton [18] asserted that different dimensions of livability vary, including social, economic, and subjective indicators that relate to the quality of life and wellbeing of dwellers.

Based on previously mentioned references of livability, it is obvious that the concept has various parameters and indicators that vary by study. Indicators are analyzed to develop a livability criteria list to be utilized in this research for assessing livability in districts and neighborhoods of emerging cities. [19] Urban regeneration is also reviewed to address the important guidelines that contribute to conserving the identity and the character of a place. The aim is to protect the heritage and traditional values of neighborhoods and establish a link to the sociocultural layer of the built environment. A review of the previous literature reveals several parameters for livability, such as comfortable and protected shelter, healthy neighborhoods free from pollution and traffic congestion, and neighborhoods that have a sense of community and identity [7].

As a concluding remark, Lynch [16] defined livability using a number of values and dimensions while Vuchic [17] defined livability as being "generally understood to encompass those elements of home, neighborhood, and metropolitan area that contribute to safety, economic opportunities and welfare, health, convenience, mobility, and recreation". Published papers were reviewed to justify these parameters, validate the indicators, and develop the research framework.

\subsection{Urban Regeneration}

Urban regeneration has been defined as a comprehensive planning tool that seeks to solve urban problems and leads to permanent development in the environmental, physical, economical, and social aspects of a city that have been redeveloped and regenerated [20]. Other research has mentioned urban regeneration as an integrated action with three goals, namely equity (mitigating inequality), economy (conserving economic competitiveness), and environment (protecting the environment) [21]. Urban regeneration involves processes and strategies for the replanning of areas that need to comply with the regeneration goal; to develop the physical aspects of an area; to increase economic growth while also considering environmental sustainability. Roberts [20] indicated that it is crucial to understand the differences between urban redevelopment, urban regeneration, and urban rehabilitation. The first term entails a full development process and does not have well-known aims. Urban regeneration has a comprehensive development process that involves developing a district's infrastructure, increasing economic prosperity, and conserving old buildings. Regeneration can be defined as the revival and 
renewal of an area, including strategies for economic, social, and environmental development that would allow the city to conserve valuable properties [4]. Considering the sociocultural aim of urban regeneration, Gehl [22] suggested that there is a need to restructure public spaces to support and facilitate public gatherings and enhance public communication and contacts among people.

\subsection{Qatar National Development Framework 2032 (QNDF)}

Doha is one of the fast growing and evolving cities in the Arabian Gulf region and the entire Middle East and North Africa (MENA) region compared to other struggling cities [23,24]. In an institutional effort to mitigate the challenges of urbanism in the 21st century, the State of Qatar announced the National Development Framework 2032 as a national policy document to provide guidance, visionary approach, and implementing strategies of urban planning and design responding to the growing global challenges in urbanism [25]. According to QNDF, policies are tailored to the contextual realities of Qatar with cultural heritage preservation set as a priority characteristic of the anticipated built environment of Qatari cities and towns.

The QNMP 2032, Qatar National Master Plan, sets out short term and long-term roadmaps priorities and goals for the country's urban growth. All huge projects need to be done by 2026 as per the plan. For instance, transportation system construction, highways facilities, local railways, light rail systems, and transport facilities for regional transit [26]. Finally, the QNDF-2032 design strategy allows for a typical hierarchy for urban centers. That region of the West Bay, airport, and the city center governmental district constitutes the core of Metro station in Doha while others are compact, express-oriented regional centers and city centers link via radial, transit corridors. The viability, reputation, and future mega-projects with the existing one's integration are considered as essential to the main policy priorities of that programme. Scale, the creation of mixed uses, and the centers hierarchy are viewed as the main spatial principles that will create a change in Doha.

Hence, the research study refers to the QNDF in developing an urban design scheme for the urban regeneration of the West Bay Business District, while considering the theoretical aspirations from the literature of sustainable urbanism, livability, and urban regeneration. To conclude, urban regeneration expresses its process as "the revival of our lost placemaking art .... Reorganization of the urban community as full settlements, towns, villages and neighborhoods-the manner in which societies have been developed worldwide for decades". The process's key aim is to build more walkable environments focused on people rather than automobile focused and based neighborhoods. West Bay is placed as a major TOD on the red transit line. The recent rail line aim is to support the development and reconstruction, renovation, and regeneration of the city, which is now dormant since the lack of open space and the presence of skyscrapers, failure to communicate between the front and building and access destinations, ineffective green space provision, etc. [27].

\subsection{Case Study Settings: West Bay: The Central Business District in Doha}

L. Pereira international planning and consultancy firm was appointed by the Qatari government in 1975 to design the new district of Doha West Bay (Figure 2). The design is based on land reclamation policies to avoid land acquisition from the private landowners [28]. The initial program of the project involved housing for senior Qatari citizens, a diplomatic zone, governmental centers, and the Corniche as the waterfront promenade. The main focal point for investment was the building plots that were developed individually at various phases by private developers. At a later stage, Al Montaza Park Gardens was created in the 1980s, while Al-Bidaa Park and the Corniche were developed in the 1990s. In 2001, the city center, which is the business hub of Doha, was incorporated. Most of West Bay land area is incorporated in the two significant metropolitan zones 60 and 61 . They comprise $8 \mathrm{~km}^{2}$ of land with smaller 70 subzones distributed into 130 plots. The land connected to water as it incorporates $5 \mathrm{~km}$ of coastline and $3 \mathrm{~km}$ of internal land. The area includes significant buildings, for example, The Sheraton hotel that was built in 1982 and verified as the oldest structure in the area; City center shopping mall; Doha Exhibition and convention centre; a large number of residential and 
administrative towers. West Bay has experienced a few significant insufficiencies, urban planning has prompted a disconnected mass of high rises, an absence of incorporated open spaces, no vehicle substitute for laborers, and a lack of services for nearby occupants. Therefore, the new West Bay TOD requires careful planning and development to promote the growth of culturally diverse urban form. The small public spaces within and near the buildings and surrounding are inadequate. The huge Sheraton Park is $1.3 \mathrm{~km}$ from the current train station. Despite the absence of coordinated open spaces, the current green spaces are present only for aesthetic reasons and cover $45 \%$ of the district.

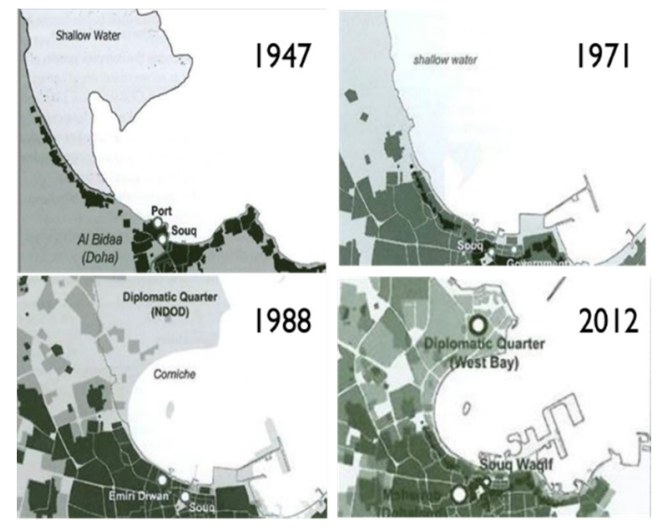

(a)

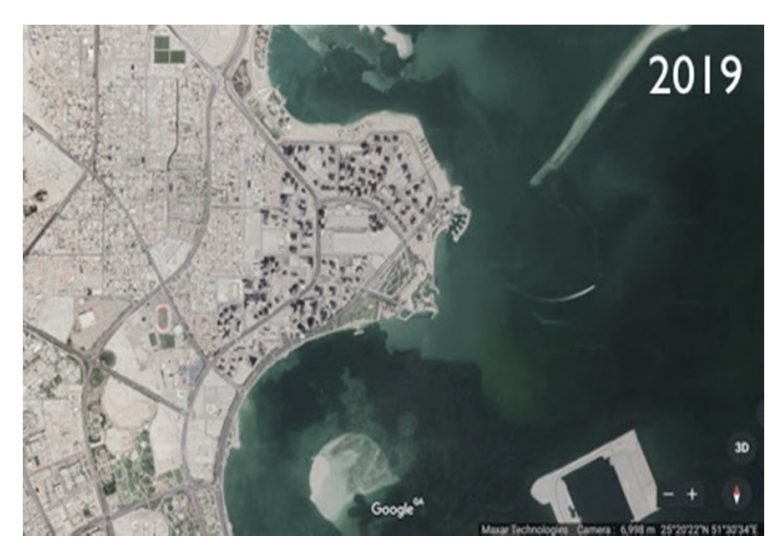

(b)

Figure 2. (a) Urban pattern throughout the history (source: Adapted from [21]) (b) current urban pattern 2019 (Source: google earth).

\section{Materials and Methods}

Urban design is an evaluative process where individuals learn as they go through with it. They get to know goals and means as interpreted by key parties, they gain from the proof that each offers for their own views. Urban design is the practice of planning and executing building communities, streets and the public domain between the structures, communities and/or suburbs, or the urban setting of cities on a wider scale, depending on the needs of the individual and its established by multifaceted variables such as lifestyle, human actions, and/or human activity. The main goal of urban planners is making city-forming urban areas more livable, efficient, desirable, and sustainable. However, urban architecture is an interdisciplinary topic, which requires an awareness and understanding of wide interdisciplinary topics from scientists, sociologists, economists, planners, and engineers. The purpose of this research study is to investigate and evaluate West Bay's established conditions against the TOD criteria to describe them as a program to rebuild the region and make it more livable for all people. This is achieved by evaluating the relevant facts and literature outlining the main factors to be tackled in the creation of TODs and systematic data analysis. For this research study the overall research design for data collection is through the analysis of the multidisciplinary literature: sustainable urbanism, livability, and urban regeneration and their relevance to the Qatari Framework for National Growth (QNDF-2032). Classification of main factors to create TODs, for instance, diversity of land use, density of land use, urban architecture, accessibility, livability, infrastructure, and public realm through a thorough analysis of the West Bay area; a modern CBD in Doha which is selected as the case study.

The research addresses the case of West Bay Central development, namely how the urban form can be enhanced in terms of the principles and potential of urban regeneration and development in the West Bay district, in addition to the challenges and constraints that affect its livability (Figure 3). Therefore, the study aims at exploring its urban form and built environment through relevant literature and an investigation process analyzing land uses, diversity, density, transportation, and accessibility. Therefore, the research design consists of two main stages: 


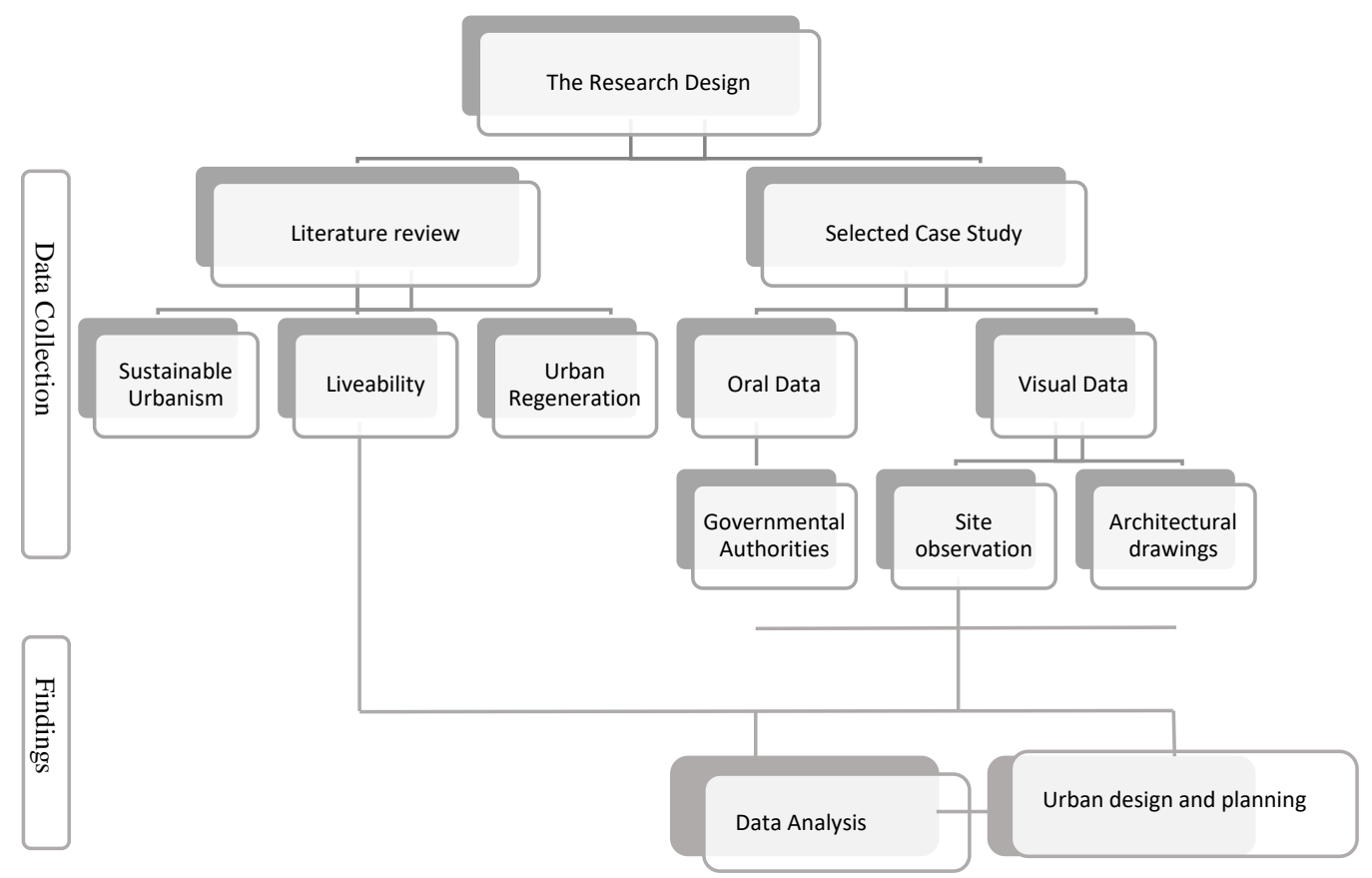

Figure 3. The research design diagram.

(1) Literature review: this will be done through a theoretical review that highlights the factors of livable space, in addition to qualitative data collected from planners and executers and researchers to evaluate the conditions and work on its regenerative schemes. Drawing back on previous studies that examined neighborhoods livability, such as the quality of urban life and perception of livability by Omuta [8]. In addition to Furlan [4,29] and Al Saeed [30], focusing on generating a scheme to enhance Doha's neighborhood livability. In addition, the review of relevant concepts outlined in the literature, such as sustainable urbanism and urban regeneration addressing the key factors and parameters of livability in relation to the principles of urban design and TOD.

(2) Examination of the West Bay area, the area under investigation with oral and visual data as follows: oral data were collected by semi-structured interviews conducted with the authorities from Qatar Ashghal Public works, Ministry of Municipality and Environment (MME), and Qatar Rail. Visual data were collected through site visits and observations, site maps, architectural drawings, and photographic documentation. Moreover, examining data collected and evaluating West Bay's pre-existing conditions more precisely to determine the categories to be analyzed; a thorough site analysis of the selected area adopted by transit-oriented development (TOD) key strategies [5]: (1) diversity of land use and density of land uses, (2) urban design and connectivity, (3) modes of mobility and efficient public transport system. These factors are considered for the development of the masterplan, the guidelines of which are based on the principles adopted as follows: (a) for the urban regeneration of the West Bay district, (b) for enhancing livability of the district, on the following basis to create a schematic strategy for regenerating and enhancing the district.

The concept of urban design involves the alteration and reshaping of the physical features of city districts, neighborhoods, municipalities, streets, and public spaces with the aim of making urban areas livable and sustainable. Urban design theory contributes in public spaces management and design according to human needs by addressing many factors, including physical, sociocultural, functional, and environmental factors. [12] In the current era, one of the major challenges of urban design and planning is the over-dependence on vehicular access and the automobile to define the built environment, either intentionally or by virtue of chance. Automobile-oriented design retransformed priorities of urban design, as the city layout had to include roads and highways and urban areas had to sprawl. Such practices divided the city and separated the compact neighborhoods, which affected social interactions and the livability of open public spaces. The concept of new urbanism aims to create 
a sustainable built environment through compactness and intensification, with livable and walkable open spaces. Utilizing TOD and developments centered on walkability would lead to various benefits on the urban scale including the reduction of environmental impacts. The compact neighborhood is another approach of new urbanism to reduce travel distances and minimize urban sprawl. From the brief review of the previous literature, it is recognizable that walkability, accessibility by various forms of public transportation, continuity, mixed use development, pedestrian connectivity, and green spaces are major components of a livable city model. [31].

\section{Results}

In this research study, the findings are planned into three main section: (1) analysis of the selected area; (2) master plan proposal based on TOD factors; (3) urban planning strategies and guidelines associated within the urban design focusing on land use, and transport system integration. The West Bay area was analyzed through TOD sustainable key factors including:

1. Diversity and density;

2. Urban design;

3. Transportation and infrastructure.

\subsection{Site Analysis}

\subsubsection{Diversity and Density}

Within an urban environment characterized by broad streets, the West Bay area includes a combination of residential, commercial, public spaces land use. Approximately 50\% of land use comprises commercial office, 10\% residential multifamily, 15\% residential single family, 15\% special usage, and $10 \%$ neighborhood facilities/total city open space. The following Table 1 indicates the density-level inside the region under investigation. In the main area, the high dense envelopes are obvious in the southern corridor, which are for commercial usage. Residential units are located in the north with medium density. While on the other hand, empty green land as illustrated in Figure 4 shows that it has a low density. To examine density more closely, it is divided into three main types studied below.

Table 1. West Bay Doha population density (source: author, retrieved from planning and statistics authority in Qatar).

\begin{tabular}{cccc}
\hline West Bay & Population & Area & Population Density \\
\hline Zone 61 & 4022 & 4.0 & 1004.6 \\
Zone 60 & No data & No data & No data \\
\hline
\end{tabular}

The first type is built form density, which shows structures and open land proportion. The second type is vehicle density that is related to built-form density. The circulation of the vehicular access is high during the day and tends to increase during the rushed working hours due to the land use and function of the buildings in the area. The WCS station has lower density compared to DECC due to its proximity of the exhibition hall and the city center shopping mall located next to the DECC station.

\subsubsection{Urban Design}

The West Bay district is part of a significant geological area connecting the coastline to the interior area. Therefore, the Ministry of Municipality and Environment categorizes the area as a special development zone (SD ZONE). The arrangement of the SD zone allows permitted projects to incorporate tall buildings and governmental administrational centers. By focusing on the surrounding stations with a radius of $450 \mathrm{~m}$, it is shown that the main use of the land is for governmental buildings and West Bay Central station (WBC), notwithstanding a few specific facilities such as research centers, 
commercial companies, and ministries. Nonetheless, the radius also includes residential facilities in the area. The Doha Exhibition and Convection Centre (DECC) station incorporates open space and social services, for example, a large exhibition center and authorities' Head Quarters, as well as hotels and shopping centers such as the City Center Mall as seen in Figure 5.

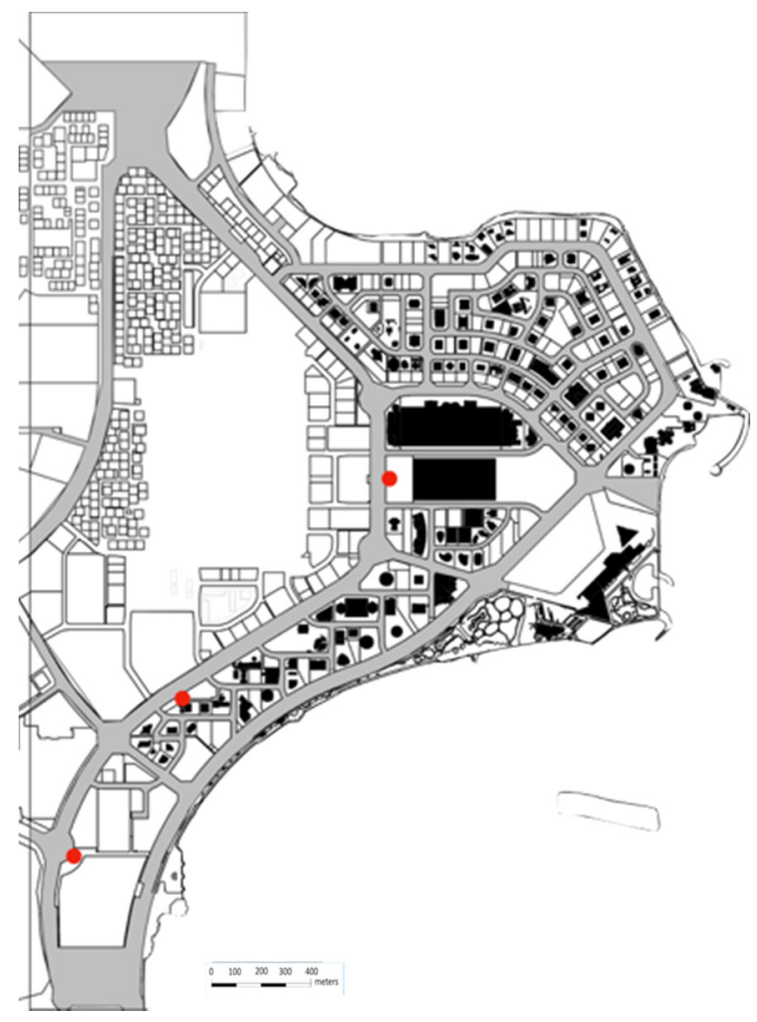

Figure 4. West Bay Doha Built form.

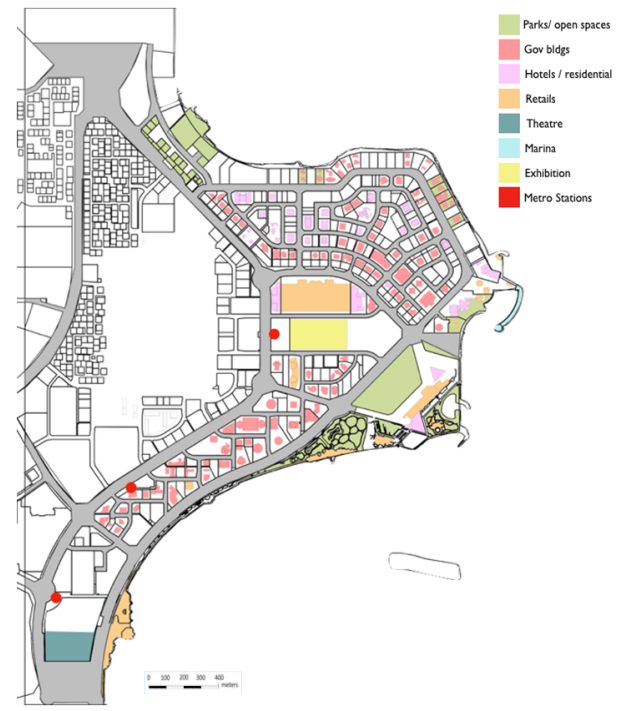

(a)

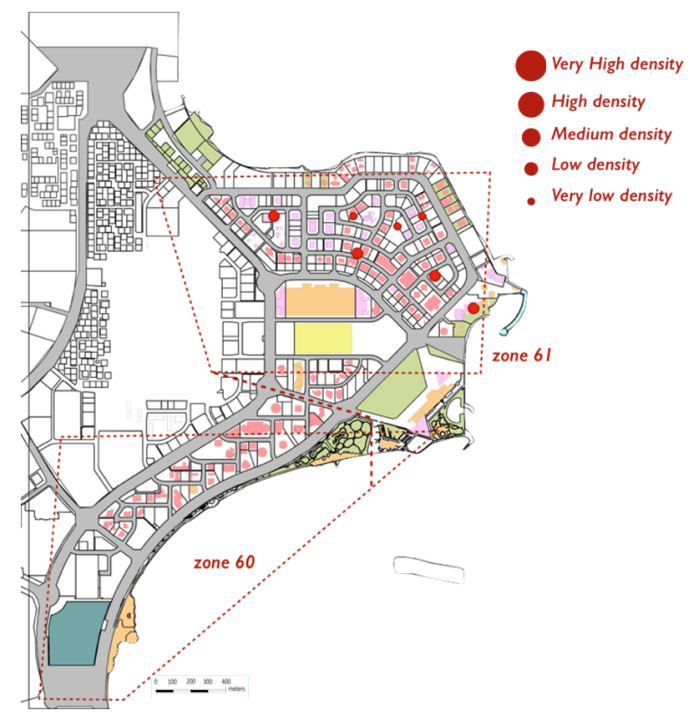

(b)

Figure 5. (a) West Bay Doha land uses; (b) West Bay Doha density.

The functional use of the West Bay area includes several residential and business land uses. Residential flats for families account for around $15 \%$ of the total area, multifamily residential units account for around $10 \%$, commercial offices account for $50 \%$, special use structures account for $15 \%$, 
and open community spaces account for $10 \%$. The existing of business and government buildings in the area created the contemporary image of the West Bay as a futuristic, modern landmark of the city associated with its ambitions and global aspirations. Except for the distinctive Sheraton Hotel building, most of the high-rise buildings and towers exhibit similar architectural forms and trends, where they collectively represent an image of the contemporary skyline of a global city. Due to the lack of space between buildings, open green spaces are currently present only for aesthetic reasons and there is a lack of actual open spaces designed for public use. The series of parks on the north-eastern edge of the West Bay are well designed and equipped with various public facilities such as open markets, water features, shades, and seating areas. Meanwhile, there is a limited proximity between the highly dense towers and the parks corner, leaving the inner parts of the West Bay vacant and in lack of green integration. In September 2019, Al Abraj Park was inaugurated in the West Bay area sponsored by Ashghal Public Works Authority, under its supervisory committee of beautification of roads and public places in Qatar [32]. The park is located in walking distance vicinity to major administrative, governmental, and headquarter buildings, presenting an active green nod to employees and visitors of the area as shown in Figure 6. Such collaborative and partnership efforts between the wide range of stakeholders including governmental authorities is beneficial in accelerating the pace of change anticipated to regenerate the West Bay area and other active sites in the city.

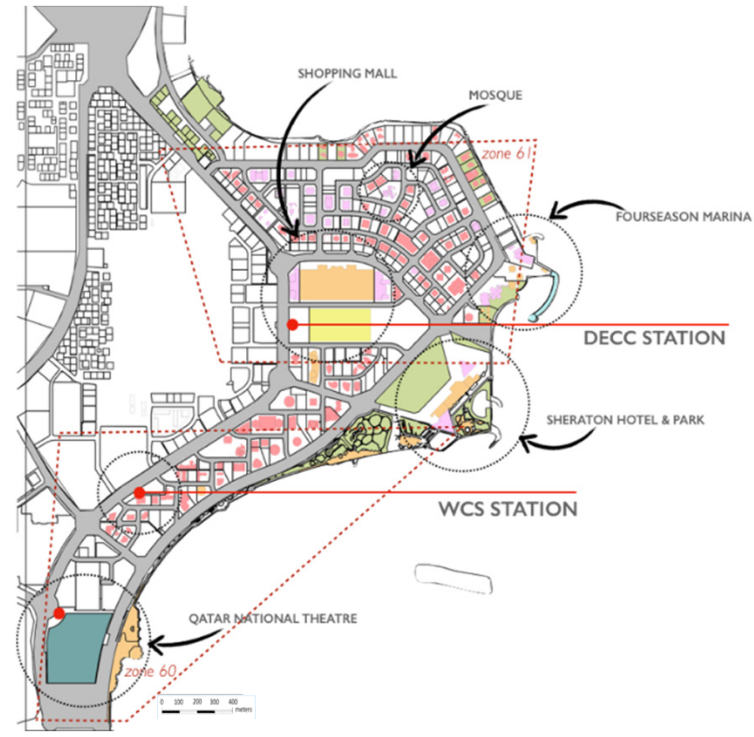

(a)

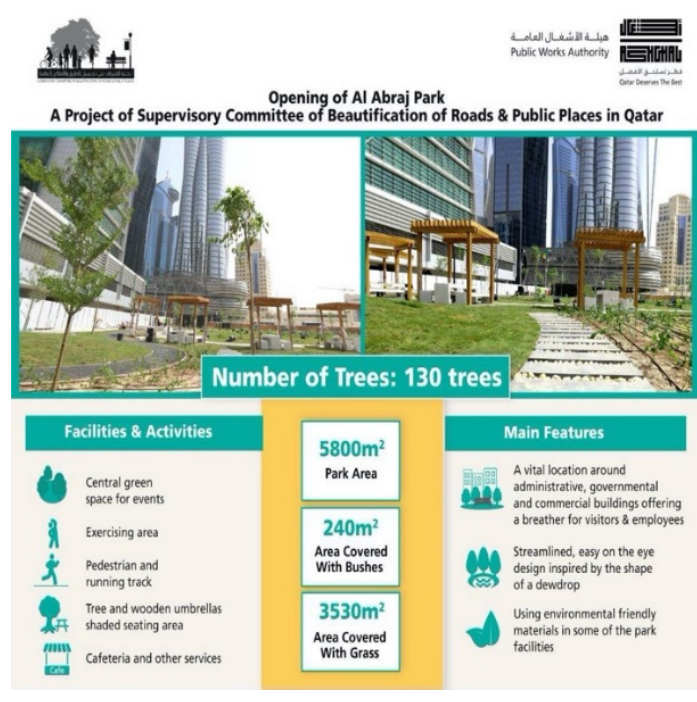

(b)

Figure 6. (a) West Bay Doha landmarks; (b) public space in West Bay Doha [32].

\subsubsection{Transportation and Infrastructure}

Since West Bay has a curved shoreline, the landform has affected the streets and reshaped them naturally in a radial way (Figure 7). The area's primary streets are the Corniche Road from the south-east and Majlis Al Taawon and Omar Al Mukhtar from the north-west. Numerous auxiliary streets pass through the area connecting the major streets, such as Conciliatory Road, Al Funduq Road, Conference Center Road, and Al Markhiya Road. West Bay has two major access points, from the north through Omar Al Mukhtar Road and from the south through Al Markhiya Street. The activity on the major streets of West Bay, namely the Corniche Street and Majlis Al Taawon Street, is overwhelming particularly during the rush hours of the weekday from 7:00 am to 2:00 pm, when people travel to their workplaces or visit legislative or administrative offices and in the evenings from 5:00 pm to 7:00 pm. In the summer, when the temperature is unbearable during the day, dense pedestrian and vehicular movement can be observed from 5:00 pm to 12:00 am on the Corniche Street. The major lanes can be considered as a vertical hub that connects Doha's cultural core with unused development ranges at the 
West Bay. On the Conference Center Road and Al Funduq Road, vehicle traffic is overwhelming since these roads serve the City Center Mall, the Doha Convention Center, the diverse commercial buildings and different lodgings. At the intersection of Majlis Al Taawon Street and the Corniche Street, there is widespread of vehicle-oriented development since the zone primarily includes private buildings and empty land.

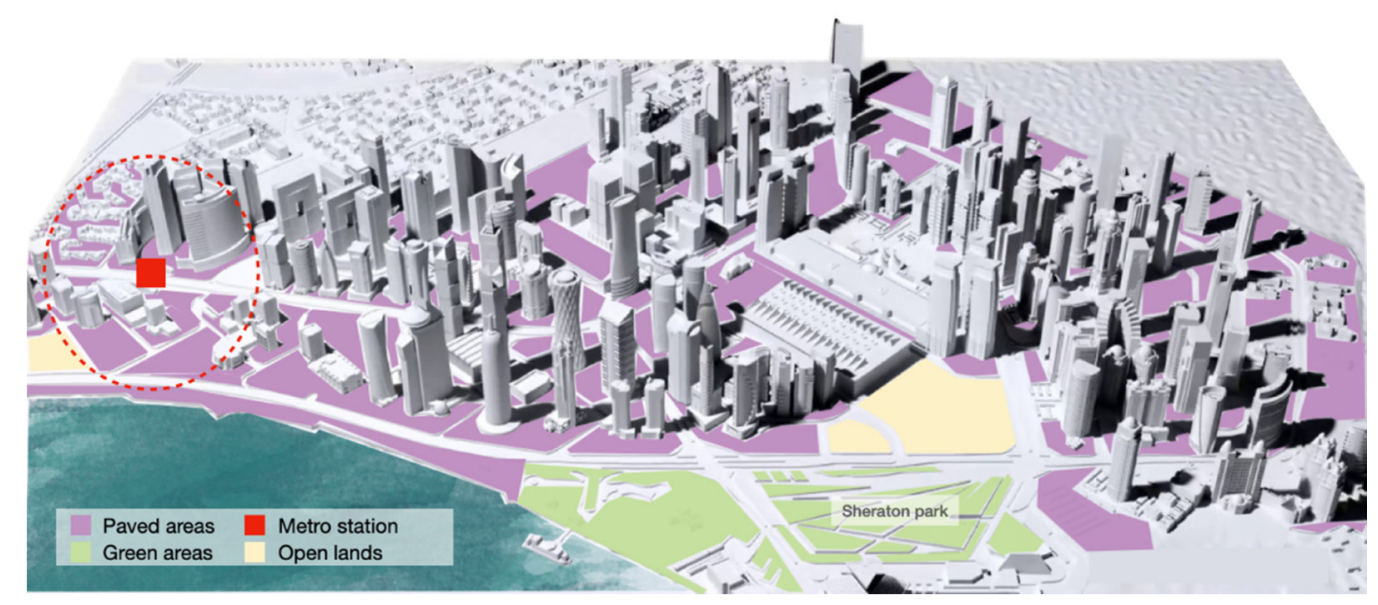

Figure 7. The public realm pattern in West Bay Doha.

It essential to note that people often utilize empty lots as parking spaces since it can be difficult to find a stopping area in the Corniche with its one-way access as well as the limited public parking spaces of towers and high-rise buildings. Yet, there is a municipal effort to provide sufficient park and ride sites covering the West Bay area to reduce the traveling distance and familiarize the use of bus shuttles as an alternative public transportation option. Due to the high utilization of cars as the primary mode of travel in the area, there is a need for pedestrian-friendly connectivity along with shaded walkways and solar management techniques. The Ministry of Transport and Communication funds West Bay shuttle services operated and managed by Mowasalat Company. The exclusive service has 36 stops on a circular route and runs every $12 \mathrm{~min}$ from 6 am to $9 \mathrm{pm}$ during the week. The exclusive circular routes cuts across the West Bay business district and its associated hotels [33].

In West Bay, there are different transportation modes, including public buses that stop at well-distributed bus stops near the most famous buildings and landmarks in the district, such as the Sheraton Hotel, City Center Mall, Gulf Mall, Doha Exhibition and Convention Center, government buildings, and the Corniche Street. A Metro line serves the district through two metro stations at DECC and WBC, which are connected with the Route 2 shuttle bus.

The transportation system in the district has four different main transits crossing and circulating the entire area. The infrastructure links the district with the internal and external immediate surrounding areas. The transit types are (1) the two stations (WCS, DECC) metro networks adjacent to zone 61; (2) red and blue shuttle buses lines connecting all sections of the district passing by the most dominant locations; (3) a taxi meeting point station, which is located next to the city center shopping mall; (4) private vehicles as the most used transportation type in Qatar as seen in Figure 8.

Considering the location of metro stations, the WBC station is located apart from the district while DECC station is located in the middle of the district. Compared to the WBC station, the DECC station is used more often due to its accessible location and proximity to busy nods (Tables 2 and 3). Yet, both stations operate continuously serving all the buildings in the area, while linking the district to the rest of the city. The diversity of users in the area proves the importance of location choices of the metro stations, which influence the urban fabric factors such as density, land use, and accessibility. The West Bay has an extremely limited pedestrian network that connects the amenities in the district to each other or connects it with the surrounding areas such as the Corniche Park and the Sheraton Park. Thus, residents of the West Bay totally rely on vehicles for short trips. The site analysis reveals that 
there is a pedestrian route in the Corniche Park and the Sheraton Park, while a cycling route exists only in the old Sheraton Park, as shown in Figures 9 and 10. In addition, pedestrian crossroads are distributed mainly on the main arterial ways with a noticeable large distance between them. There are few safe road intersections or car-free zones between buildings, which pushes residents and users to use their cars for even short trips. Besides the pedestrian and running track at Al Abraj Park and the cycling track of the Corniche road, there are no cycling routes in the West Bay as contemplated through site analysis. Thus, there is a need to restructure the current bicycle network along with the proposed pedestrian network for the vicinity or permanent segregation of the main roads to make cycling easier and safer. Qatar's public transport systems envisage feasible urban transformation, preserved through the creation of unused open transport frameworks, Doha's Metro, and the public transport network. In this way, integrating the two main open systems under development is of a cardinal importance, so that the reliance on private cars is decreased.

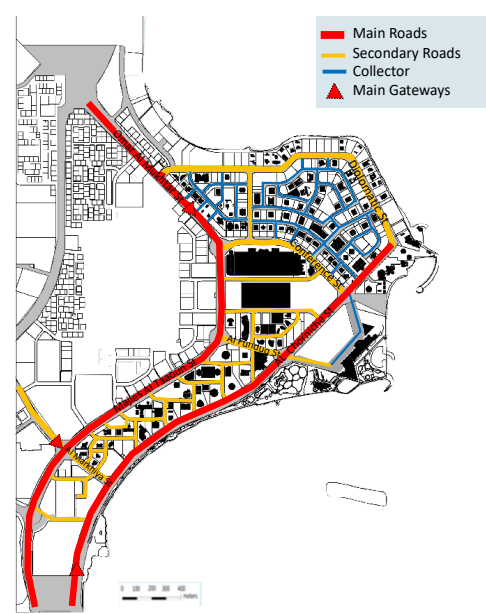

(a)

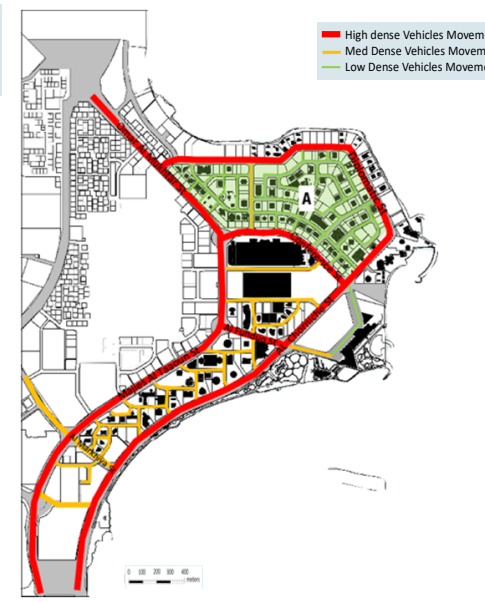

(b)

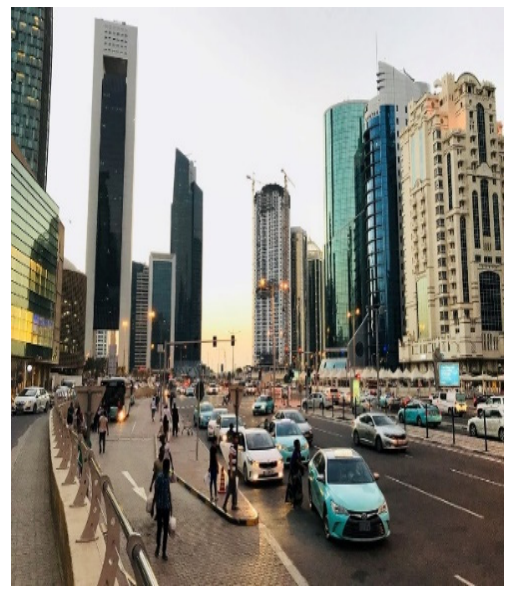

(c)

Figure 8. (a) West Bay Doha street network map; (b) West Bay Doha vehicle movement; (c) taxi station next by the city center shopping center.

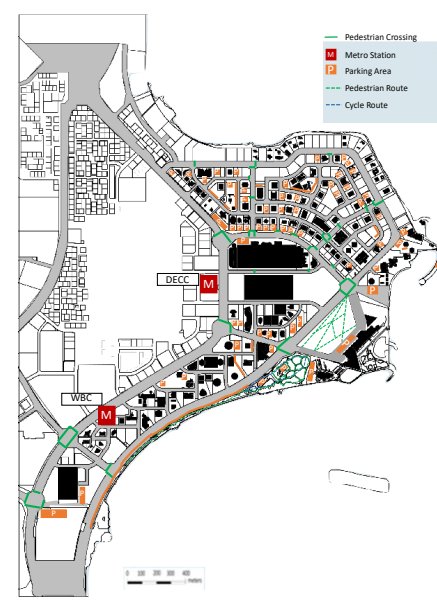

(a)

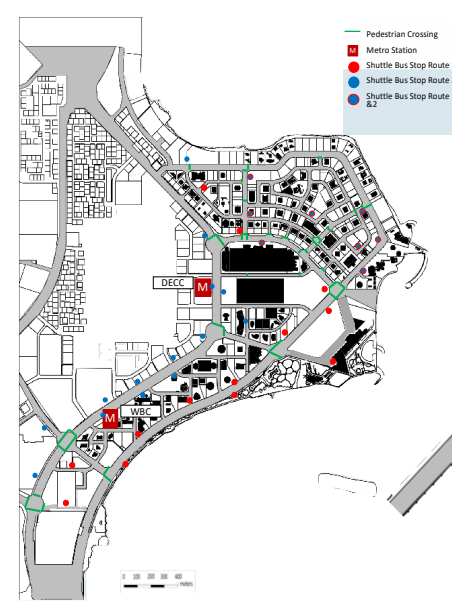

(b)

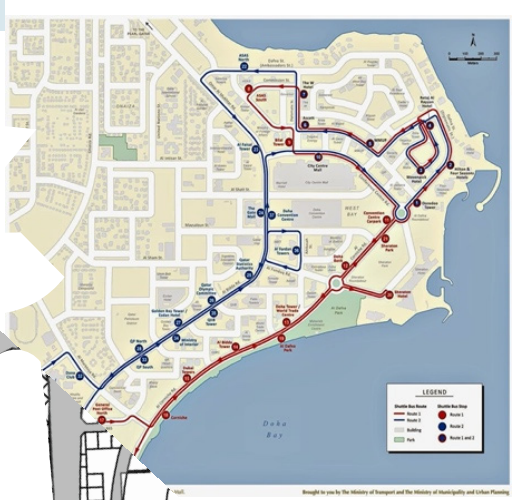

(c)

Figure 9. (a) Pedestrian, parking, and cycling map in West Bay; (b) transportation map in West Bay; (c) bus shuttle routes map in West Bay (source: the Ministry of Transportation and Ministry of Municipality and Environment in Qatar). 
Table 2. The distance via transportation modes between West Bay Metro stations and nearby landmarks.

\begin{tabular}{ccccccc}
\hline WBC Station & $\begin{array}{c}\text { Costa } \\
\text { Coffee Shop }\end{array}$ & $\begin{array}{c}\text { Qatar } \\
\text { National Museum }\end{array}$ & Al Bidaa Park & $\begin{array}{c}\text { Qatar } \\
\text { Post Office }\end{array}$ & $\begin{array}{c}\text { Qatar } \\
\text { Sports Club }\end{array}$ & $\begin{array}{c}\text { Qatar } \\
\text { National Theater }\end{array}$ \\
\hline Distance & $3.3 \mathrm{~km}$ & $2.2 \mathrm{~km}$ & $2.2 \mathrm{~km}$ & $1 \mathrm{~km}$ & $950 \mathrm{~m}$ & $1.1 \mathrm{~km}$ \\
Car & $7 \mathrm{~min}$ & $4 \mathrm{~min}$ & $5 \mathrm{~min}$ & $3 \mathrm{~min}$ & $7 \mathrm{~min}$ & $3 \mathrm{~min}$ \\
Bus & $25 \mathrm{~min}$ & $7 \mathrm{~min}$ & $17 \mathrm{~min}$ & $3 \mathrm{~min}$ & N/A & $14 \mathrm{~min}$ \\
Walking & $30 \mathrm{~min}$ & $18 \mathrm{~min}$ & $27 \mathrm{~min}$ & $13 \mathrm{~min}$ & $12 \mathrm{~min}$ & $14 \mathrm{~min}$ \\
\hline
\end{tabular}

Table 3. The distance via transportation modes between West Bay Metro stations and nearby landmark.

\begin{tabular}{ccccccc}
\hline DECC Station & $\begin{array}{c}\text { Costa } \\
\text { Coffee Shop }\end{array}$ & $\begin{array}{c}\text { Four } \\
\text { Seasons Hotel }\end{array}$ & Sheraton Park & $\begin{array}{c}\text { City } \\
\text { Center Mall }\end{array}$ & $\begin{array}{c}\text { Qatar } \\
\text { Sports Club }\end{array}$ & $\begin{array}{c}\text { The } \\
\text { Gate Mall }\end{array}$ \\
\hline Distance & $1.4 \mathrm{~km}$ & $1.4 \mathrm{~km}$ & $1.6 \mathrm{~km}$ & $1.5 \mathrm{~km}$ & $950 \mathrm{~m}$ & $1.9 \mathrm{~km}$ \\
Car & $5 \mathrm{~min}$ & $5 \mathrm{~min}$ & $6 \mathrm{~min}$ & $4 \mathrm{~min}$ & $7 \mathrm{~min}$ & $7 \mathrm{~min}$ \\
Bus & $16 \mathrm{~min}$ & $15 \mathrm{~min}$ & $12 \mathrm{~min}$ & $8 \mathrm{~min}$ & N/A & $10 \mathrm{~min}$ \\
Walking & $17 \mathrm{~min}$ & $17 \mathrm{~min}$ & $12 \mathrm{~min}$ & $9 \mathrm{~min}$ & $12 \mathrm{~min}$ & $10 \mathrm{~min}$ \\
\hline
\end{tabular}

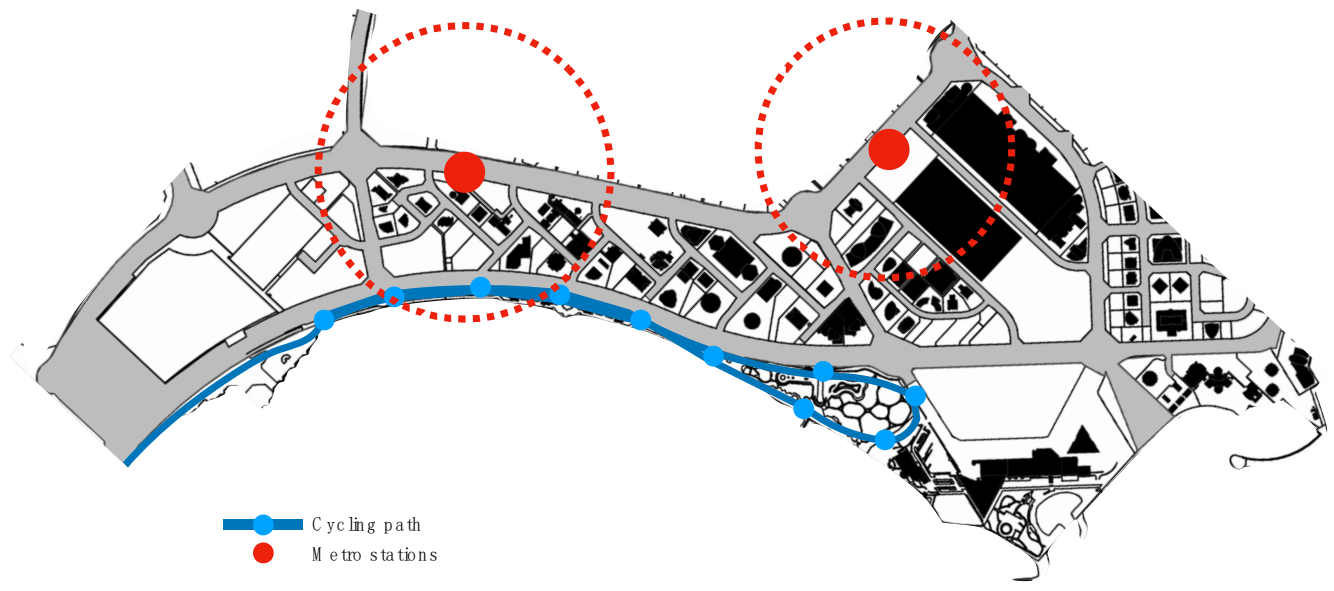

Figure 10. Corniche cycling network pattern.

\section{Discussion}

In regard to the SWOT analysis, the strengths of the West Bay area are (1) existence of high-end buildings with unique contemporary appearances; (2) existence of a variety of mixed-use buildings (3) representation of Doha's new Central Business District. While the weaknesses are: (1) lack of pedestrian networks and pedestrian-friendly infrastructure; (2) poor road conditions and lack of street attractiveness; (3) increased traffic due to commercial buildings, which have been built in the area with no connections; (4) lack of vehicular parking spaces where people need to wait for long periods for valet service and private transport. The threats noticed in the area are (1) road safety and traffic congestion affecting pedestrian movement; (2) security and privacy deficits. Lastly, there are potential for some opportunities in the studied area, such as (1) enhancing connectivity to improve the pedestrian environment; (2) reduction of traffic congestion through the unused public transport systems; (3) regenerating public open spaces to improve efficiency and/or quality of life.

Concerning pedestrian density, there is a huge lack of pedestrian-friendly solutions to balance the growing density in vehicular circulation and built forms. Examples of required pedestrian connectivity solutions include cycling tracks, open green areas, compact walkways, and shading devices. Low pedestrian density in the area is noticeably seen as there are few people who tend to walk, although as the weather in Doha gets mild, more pedestrians are spotted in the streets. Thus, the challenge in the West Bay is purely an urban design challenge that must respond to the need of the public for pedestrian connectivity. 


\subsection{Master Plan-Urban Design}

The master plan of West Bay regeneration is done through policies based on livability, with a focus on the community needs for everyday activities around the area, allowing social interaction and shaping high standard of life quality and urban environment. The investigation led to the need to address three key points: (1) reducing automobiles, promoting diverse transport modes, and encouraging pedestrians; (2) promoting connectivity and minimizing isolation, increasing proximity and growth of density; (3) improving quality of life and natural environment, as illustrated in Figures 11-16.

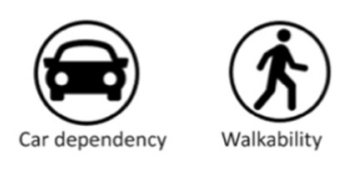

Figure 11. Encourage Walkability and Reduce Car Dependency.

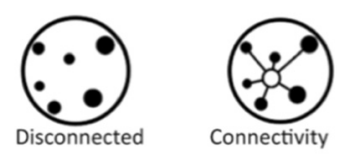

Figure 12. Promote Connectivity and Minimize Isolation.

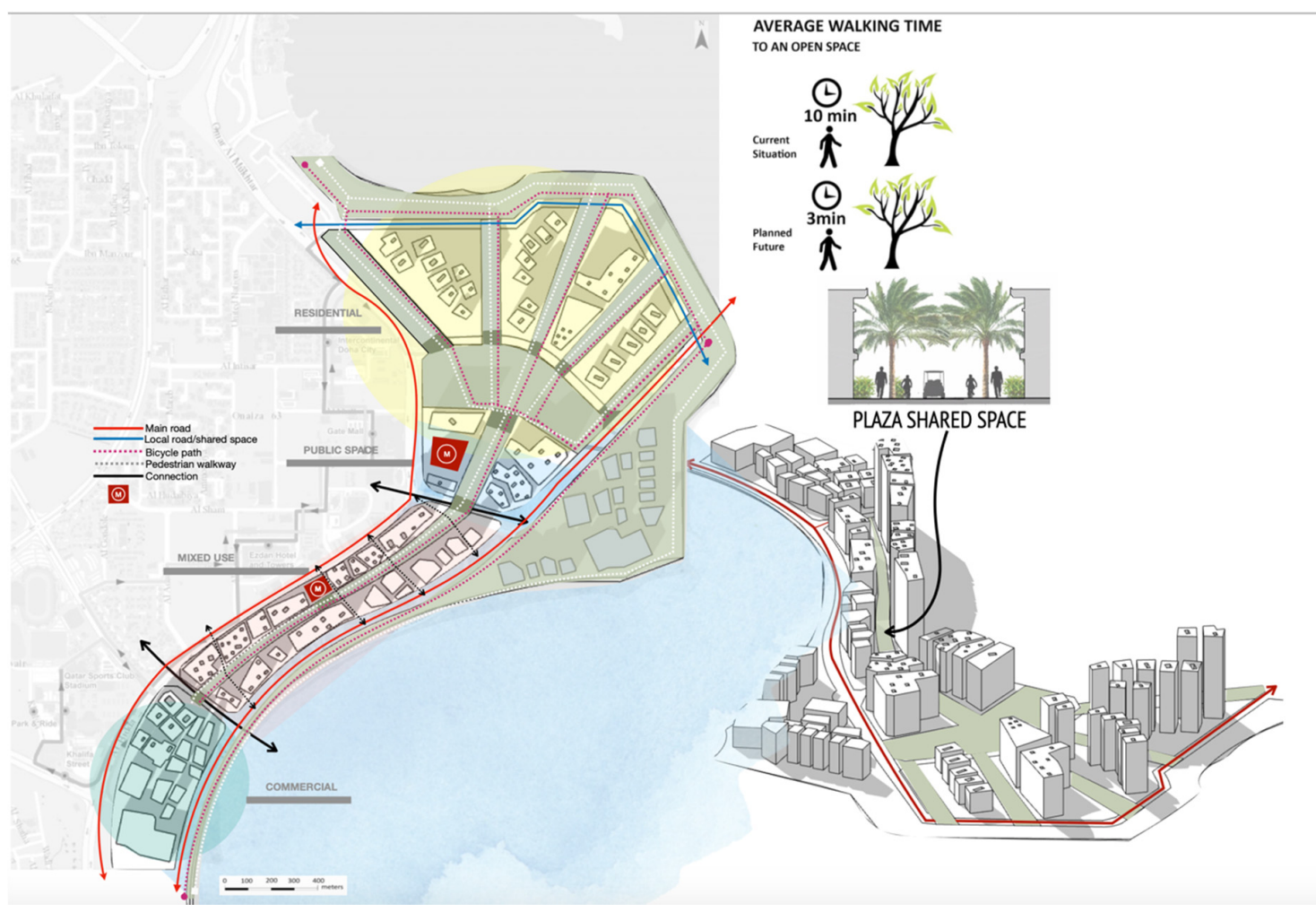

Figure 13. Proposed master plan for the West Bay area.

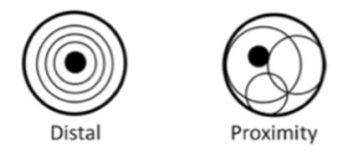

Figure 14. Increase Proximity and Decrease Distal Limitation. 


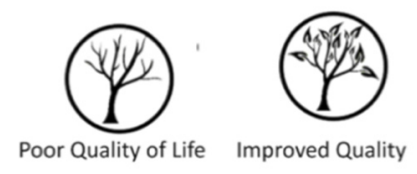

Figure 15. Improve Quality and Discourage Poor Quality of Life.
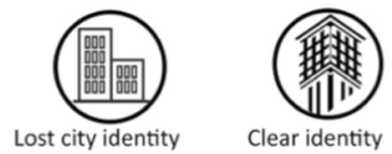

Figure 16. Foster a Clear Identity and Sense of Place.

\subsection{Master Plan Guidelines and Strategies-Urban Planning}

"The measure of any great civilization is in its cities, and the measure of a city's greatness is to be found in the quality of its public spaces, its parks and squares".

一John Ruskin

\subsubsection{Encourage Walkability and Reduce Car Dependency}

The West Bay regeneration proposed in this project includes a community with limited car access and enhanced pedestrian connectivity shown in Figures 11 and 13. Roads within the site under study are all considered to work as shared spaces. This means the roads should accommodate pedestrians, cyclists, golf cars, and other forms of transport schemes. Users should be able to get to any destination within the site easily. Another level of pedestrian walkways will be located between building units and the two public transit metro stations connections will also serve the site.

\subsubsection{Promote Connectivity and Minimize Isolation}

A general challenge analyzed in the West Bay is the disconnectivity of open spaces illustrated in Figure 12. The challenge motivates the concept of open spaces to be a key proposal of the project, especially for the inner spaces of the West Bay that lacks connection to active nodes. Suggesting well-treated open spaces that are highly connected is a solution to mitigate isolation either of land uses or functional aspects. The central space will obviously serve the whole area, with proximal distances to all the amenities and public facilities. Recreational and functional open spaces will be available around the site. Cycling paths and pedestrian walkways will also be present around the site. All roads will function as shared spaces. There will be a distinct difference in the appearance of the previously developed area and the proposed master plan Figure 13.

\subsubsection{Increase Proximity and Decrease Distal Limitation}

Public transport stops represented by Metro stations will be provided within walking distance of residences and workplaces. A modular city structure will be composed of small urban cells or proximity units on a pedestrian scale that would provide good access to public transport stops within walking distance, shown in Figure 14. The cells themselves will be linked with each other by public transport lines to provide a choice of amenities. Analyzing the existing amenities and recreational facilities allows planning to anticipate what is needed on the site and what should be accessible from the site to the city. Some daily needs should occur in a proximal distance within each neighborhood and within walking distance. The land-use distribution within the site follows the central place theory.

\subsubsection{Improve Quality and Discourage Poor Quality of Life}

Creating new accessible green spaces in the area to promote a livable city in the area as shown in Figure 15. Accessible green space is proposed to be located close to residents, easy to walk to, physically accessible, safe to use, and provides well-maintained facilities. This raises the need to satisfy 
multiple levels of integration through users, their transportation facilities, and their daily amenities. The need to provide open space for more people, or the concept of increasing the area of green space per inhabitant, can create a major difference in users' quality of life.

\subsubsection{Foster a Clear Identity and Sense of Place}

West Bay is an area with developments occurring very fast, and a variety of human behavior and consumption patterns. West Bay urban regeneration proposal is providing a clear identity of the city in which it supports and inspires the community. It needs to be implemented through urban forms and appearance of the buildings, yet it is also a respond to the behavioral and sociocultural patterns of users. The comparison is shown in Figure 16.

\section{Conclusions}

The study envisages that making changes is possible through livability hindrances faced at the West Bay area. The initial infrastructure of the West Bay in the 1970s, with the Museum of Islamic Art on the horizon, has changed rapidly over the last three decades. The development of high-rise buildings has extensively changed the outlook for the West Bay. There were many negatives in terms of the planning of the West Bay when the transformation was happening. There are few proper pedestrian crossings or walkable areas, and people with disabilities are completely neglected in terms of commuting in and around the West Bay.

As Al Saeed [30] stated that in most parts of the West Bay, there are networked supply routes, including the relationship built to connect street activity. Given the comfort of the forms, there is a predictable scene of extraordinarily dense buildings with a 4540-m base surrounded by parcels that do not allow commercial activities on the ground level. There are numerous parks at the other end of West Bay, but their connectivity is compromised to a great extent. People are hesitant to cross roads with their children because there are absolutely no pedestrian crossings. A few small roads are walkable among the unshaded buildings. With the exception of the Sheraton stop, attached to the Corniche's continuous green belt, green land is frequently used for the development of towers and is often used as a stopping area, the relative function of squares as social gathering places was established. The West Bay has several hubs connected to it, including City Center Mall considered as the main shopping mall in the district. The need to change the traffic flow by increasing pavements for pedestrians and cyclists will certainly affect how dynamics are shaped at the West Bay. There should be green spaces to make it possible for pedestrians to connect easily to surrounding places. Different squares could have an open or private green component. Conversely to the platform, the new urban texture is divided by secure ways and open streets whose plan generally does not react to the characteristics of the land's towers. The high-rise buildings have turned into obstacles for pedestrians, which is a consideration when designing the infrastructure of the West Bay. The sizes of blocks to meet new building infrastructure calls for integrated development, taking into account the proximity of multistory car parking structures, offices, commercial and wellness centers, special living arrangements, strict road exercises, open recreational activities, entertainment events, cultural and community activities, and other functional uses. The strategy for inclusion could include green spaces, play areas for young people, activity spaces, and open zones for social opportunities. With regard to this extreme change in the urban landscape, the towers would not be apathetic and would be encouraged to adjust their vertical land use profile.

Since most of the West Bay's planning, design, and development is under governmental sponsorship, responsible stakeholders have to plan for adaptable TODs in closeness with the noticeable increase in thickness and concentration of public life in the West Bay area. The impenetrable aspect of pedestrianization has been completely neglected in the West Bay. While there is no way for motorists to park their cars and walk on the sidewalk as there is equally no opportunity for connection between the two. 
The important challenges in Doha's urban form can be categorized as the following: (1) land use deficiency: absence of integration between facilities, amenities, services, and infrastructure which as a result caused an increase in traffic congestion because of the contradiction in transport. (2) Land use trend attributable to adaptation of downtown and suburban Western zoning concepts. (3) Transport: strong reliance on private vehicles and a shortage of public transport. (4) Density: separation by the vacant plots of land. (6) Inner neighborhood quality deteriorated. The implementation of TOD in Qatar will significantly help in resolving the current challenging critical problems caused by the sprawl of the city.

Author Contributions: The authors contributed to this research study as follows: Conceptualization, S.M.A.-T., R.F.; methodology, S.M.A.-T., R.F.; software, S.M.A.-T.; validation, S.M.A.-T., R.F.; formal analysis, S.M.A.-T., R.F.; investigation, S.M.A.-T., R.F.; resources, S.M.A.-T., R.F.; data curation, S.M.A.-T., R.F.; writing—original draft S.M.A.-T., R.F.; preparation; S.M.A.-T.; writing—-review and editing, S.M.A.-T., R.F.; visualization, S.M.A.-T., supervision, R.F.; project administration, R.F., S.M.A.-T;; funding acquisition, R.F. All authors have read and agreed to the published version of the manuscript.

Funding: This research study was developed under two grant schemes awarded by Qatar University. English editing, proof reading, and open access (OA) publication fees of this paper were supported by Qatar University (Grant ID: QUCG-CENG-19/20-4) (Grant ID: QUST-2-CENG-2020-14).

Acknowledgments: This research study was initiated as an assignment for the core course, 'Urban Design in Practice' (MUPD-711, Fall-2019) taught by Raffaello Furlan at Qatar University, College of Engineering (CENG), Department of Architecture and Urban Planning (DAUP), for the Master in Urban Planning and Design Program (MUPD). The authors would like to acknowledge the research-oriented vision of Qatar University as an academic institute supporting research for sustainable urban development in the State of Qatar. The authors would like to express their gratitude to the leading planners and architects of Qatar's government agencies and ministries, namely the Ministry of Municipality and Environment (MME), Qatar Rail (QR), Qatar Museum Authority and Ashghal Public Works Authority for their collaboration, for participating in the meetings, sharing visual data and cardinal documents relevant to the research aims, and for discussing the results and conclusion of this investigation. Finally, the authors thank the anonymous reviewers for their comments, which contributed to an improvement of this paper.

Conflicts of Interest: The authors declare no conflict of interest.

\section{References}

1. Commons, H.O. Communities and Local Government's Departmental Annual Report 2009, and the Performance of the Department in 2008-09; House of Commons: London, UK, 2009.

2. Furlan, R.; Sipe, N. Light rail transit (LRT) and transit villages in Qatar: A planning-strategy to revitalize the built environment of Doha. J. Urban Regen. Renew. 2017, 10, 1-20.

3. Sharifi, E.; Larbi, M.; Omrany, H.; Boland, J. Climate change adaptation and carbon emissions in green urban spaces: Case study of Adelaide. J. Clean. Prod. 2020, 254, 120035. [CrossRef]

4. Furlan, R. Liveability and social capital in West Bay, the new business precinct of Doha. Arts Soc. Sci. J. 2015, 6, 1-11. [CrossRef]

5. Renne, J.L. Transit-Oriented Development: Developing a Strategy to Measure Success. Natl. Acad. 2005. [CrossRef]

6. Lynch, K. Good City Form; The MIT Press: Cambridge, UK, 1998.

7. Van Kamp, I.; Leidelmeijer, K.; Marsman, G.; de Hollander, A. Urban environmental quality and human well-being towards a conceptual framework and demarcation of concepts; a literature study. Landsc. Urban Plan. 2003, 65, 5-18. [CrossRef]

8. Omuta, G.E.D. The quality of urban life and the perception of liveability: A case study of neighbourhoods in Benin City, Nigeria. Soc. Indic. Res. 1988, 20, 417-440. [CrossRef]

9. Calthorpe, P.; Fulton, W.B. The Regional City Planning for the End of Sprawl; Island Press: Washington, DC, USA, 2001.

10. Calthorpe, P. The Next American Metropolis: Ecology, Communities, and the American Dream; Princeton Architectural Press: New York, NY, USA, 1993.

11. Lehmann, S. The principles of green urbanism: Transforming the city for sustainability. Urb. Stud. 2010, 50, 1087-1089. [CrossRef] 
12. Newton, P. Urban Indicator for Managing Cities; Asian Development Bank (ADB): Mandaluyong, Philippines, 2001.

13. Urban Design Group. Urban Design Source Book; UDG: Oxon, UK, 1998.

14. Jenks, M.; Burgess, R. Compact Cities: Sustainable Urban Forms for Developing Countries; E. \& F.N. Spon: London, UK, 2000.

15. Appleyard, D.; Gerson, M.S.; Lintell, M. Livable Streets; University of California Press: Berkeley, CA, USA, 1980.

16. Bosselmann, P. Urban Transformation: Understanding City Design and Form; Island Press: Washington, DC, USA, 2008.

17. Vuchic, V. Transportation for Livable Cities; Center for Urban Policy Research: New Jersey, NJ, USA, 1999.

18. Ley, A.; Newton, P. Creating and Sustaining Liveable Cities. Dev. Living Cities 2010, 191-229. [CrossRef]

19. Lennard, S.H. Livable Cities Observed: A Source Book of Images and Ideas for City Officials, Community Leaders, Architects, Planners and All Other Committed to Making Their Cities Livable; Gondolier Press: Carmel, CA, USA, 1995.

20. Roberts, P. The evolution, definition and purpose of urban regeneration. J. Urban Regen. 2000, 9-36. [CrossRef]

21. Furlan, R.; Saeed, M.A. Strategies for the enhancement of users' social interactions in Al Mirqab Al Jadeed street in Doha, State of Qatar. Archit. Res. 2017, 7, 69-83.

22. Gehl, J. Cities for People; Island Press: Washington, DC, USA, 2010.

23. Elsheshtawy, Y. The Evolving Arab City. Tradition, Modernity and Urban Development, 1st ed.; Routledge: Oxfordshire, UK, 2008.

24. AL-Mohannadi, A.S.; Furlan, R. The practice of city planning and design in the Gulf region: The case of Abu Dhabi, Doha and Manama. Int. J. Archit. Res. 2018, 12, 126-145. [CrossRef]

25. Qatar National Development Framework 2032. Available online: http://www.mme.gov.qa/QatarMasterPlan/ English/QNDF.aspx?panel=qndf (accessed on 20 March 2020).

26. QNMP: Qatar National Master Plan. 2020. Available online: http://www.mme.gov.qa/QatarMasterPlan/ default.aspx (accessed on 20 March 2020).

27. Furlan, R. Modern and vernacular settlements in Doha: An urban planning strategy to pursue modernity and consolidate cultural identity. Arts Soc. Sci. J. 2016, 7. [CrossRef]

28. Nagy, S. Dressing up downtown: Urban development and government public image in Qatar. City Soc. 2000, 12, 125-147. [CrossRef]

29. Furlan, R.; Petruccioli, A.; Major, M.D.; Zaina, S.; Zaina, S.; Al Saeed, M.; Saleh, D. The urban regeneration of west-bay, business district of Doha (State of Qatar): A transit-oriented development enhancing livability. J. Urban Manag. 2019, 8, 126-144. [CrossRef]

30. Al Saeed, M.; Furlan, R. Transit-oriented development in West Bay, Business District of Doha, State of Qatar. J. Cult. Heritage Manag. Sustain. Dev. 2019, 9, 394-429. [CrossRef]

31. Boeing, G.; Church, D.; Hubbard, H.; Mickens, J.; Rudis, L. LEED-ND and livability revisited. Berkeley Plan. J. 2014, 27, 31-55.

32. Ashghal.gov.qa. Progress of Works of the Supervisory Committee of Beautification of Roads and Public Places in Qatar. Available online: http://www.ashghal.gov.qa (accessed on 14 March 2020).

33. Qatar Monthly Statistics. (n.d.). Available online: https://www.psa.gov.qa/en/statistics1/StatAwareness/ Pages/GlanceOnQMSReference.aspx (accessed on 20 March 2020).

Publisher's Note: MDPI stays neutral with regard to jurisdictional claims in published maps and institutional affiliations.

(C) 2020 by the authors. Licensee MDPI, Basel, Switzerland. This article is an open access article distributed under the terms and conditions of the Creative Commons Attribution (CC BY) license (http://creativecommons.org/licenses/by/4.0/). 